UDK 025.32

\title{
Tarptautinis standartinis bibliografinis aprašas
}

Osvaldas JANONIS

Vilniaus universiteto Knygotyros katedra, Saulètekio al. 9, 2054 Vilnius, el. paštas: janonis@kvb.

Plečiantis tarptautiniam bendradarbiavimui, kuriant tarptautines informacijos programas, suvokta, kad bibliografijai, kaip ir kitoms veiklos sritims, būtina tarptautine unifikacija. Bibliografijos procesu kompiuterizavimas ypac is isakmiai pareikalavo unifikuoti klasifikavimo dalykinimo principus, formatus, technines priemones t.t. Tarptautine unifikacija garantuoja bibliografinity duo meny suderinamuma, kartu ir pasikeitimo jais tarp šali mum Tarptatini standarty dieginas patied pricinatojams teikti operaty kumentus Standartinis biblio rafiniai ira ̌ai suteikia galimye suprasti veju, kaivartotojes apra galmoe suprasti j̧raşa ir tuo at tautiniu aprašo taisykliu bũtinum nowo sendru tarption terizavia teikè impulsq realizuoti siq idej Šiostraipsnio tiks są idé.

artini bibliografini apros̆ išnüdinti tarptautinị stanstruktüra atkreipti demesi i aprǒ̀ najovs, podisiustruktüră, atkreipti demesị i aprašo naujoves, padisku-

Bendras tarptaulinis standartinis bibliogratinis aprašas ISBD (G). Jị parengti $1975 \mathrm{~m}$. pasiülè Jungtinis "Anglų-amerikiečit katalogavimo taisykliy" pataisų ko ni parengti toki apraša, kuris tikty bibliotekè guojemiens visy nư̌iy dokn skelbtas 1977 metais. Vèliau nuostata dél bendrouso patautinio standartinio aprašo pasikeité. 1992 metais pataisyto leidimo anotuoto teksto tikslas buyo ne sukurt bendras taisykles kataloguotojams, o apibũdinti specio lizuoty ISBD, kuriuose pateiktos isssamesnés taisyleles instrukcijos, sandarą ir pagrindinius bruožus. Taigi leidinys tapo pagalbine priemone katalogavimo taisyllity krejjams. Kataloguotojams ir vaistybinés bibliografinés ap skaitos centrams nerekomenduojama pagal ji aprašyti konkreciu dokumentu. Jo vertimas i lietuviu ka ba pasirodé 1995 metais'

ISBD (G) išvardija visus elementus, reikalingus biblioteku fonduose esamiems visu rūsiy dokumentams aprašyti ir identifikuoti, nustato aprašo elementy išdéstymo tvarką ir jụ skyrybą. Jo pagrindinis tikslas yra garan- tuoti efektyvius bibliografiniu ịaš̌ mainus tarp ivairių saliu bibliografines apskaitos centry, biblioteku, kity informacijos jstaigu. Vadovavimasis ISBD (G) ne tik igalina vykdyt tarplautinius mainus, bet ir padeda išvengti kalbu barjero bei palengvina bibliografiniu duomeny konvertavimą i kompiuterini formata

Aprašo nuostatos apima maksimaly bibliografini duomeny apie dokumentą kieki. Valstybinés bibliogra fines apskailos central rengia issamuosius aprasus, pateikiancius visus bithosius tam tikros rüsies dokumen apraso elementus. Kitos istaigos, kurios bibliografiniu rasus renga ne tarptautiniams manams, ISBD eleme tus pasirenka savo nuożiưra. Tačiau pasirinkti elementai pateikiami atitinkamo ISBD nustatyta tvarka ir naudojant nustatytus skirmenis.

Kadangi dokumento aprašas tèra tik bibliografinio irašo dalis, kiti iraso elementai (pradmuo, dalykinè in (a) mons) valstybinès katalogavimo tai-

ISBD $(G)$ pradžioje pateikiama bendrojo tarptautinio bibliografinio aprašo sandara: išvardijamos sritys, ISBD (G) speomi nustatyti skirmenys.

ISBD (G) specialiame skyrelyje aptariama skyryba. Wekvienas apraso elementas, isskyrus pirmos srities pirmenimis skirpries pres skithe ir po jo turi butti paliekamas tarpas, isstił po jus . ir taską (tarpas Šiais atvejais paliekamas

Lenktiniai ir laužtiniai skliaustai traktuojami kaip venas skirmuo, todél vienas tarpas paliekamas prieš pirmajị lenktini ar lauźtini skliaustą, o kitas po antrojo (a) eilutés kas, tarpas, brükssys, kitu sriftu. Tokiais atvejais tašciami pries tai esancios srities Jeigu biblio esas tos srities pabaigoje dedamu tašku. pateikia, o jis yra pirmasis srities elementas duomens nenys, turintys büti pries kis srites elementas, tai skirme-

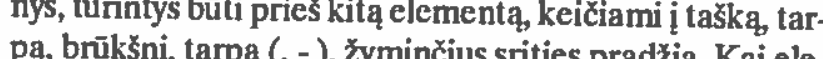

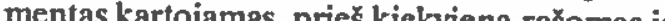

\section{Tarptautinis standartinis bibliografinis aprašas}

ISBD (G) tiksliai reglamentuoja laužtinių ir lenktinių sḱliaustu vartojimą. Bibliografui verta atkreipti dèmesi i tai, kokiais atvejais vartojami laužtiniai stliaustai. Duomenys aprašui, kaip žinoma, yra imami iš dokumento antraštinio puslapio, antraštinio lapo kitos pusès, metrikos, bibliografijos šlttiniy ir pan Specis puISBD detaliai nurodo prioritetinius saltinius, t.y. kiekvienai srižiai atitinkami šaltiniai apibūdinami kaip nustatyti duomenu saltiniai. Bibliografiniai duomenys, paimti iš kitu saltinių, o ne is nustatyto tos srities saltinio, apskliaudżami laužtiniais skliaustais, jeigu jie perrašomi kaip srities dalis. Pavyzdžiui, duomenys, imami is bibliografijos Šaltinio, pateikiami pastabos srityje.

Mūsų šalies bibliografai iki šiol buvo pratę bibliografiniame apraše gausiai vartoti santrumpas. ISBD (G) jų vartojimą labai apriboja. Beje, jis tiksliai atskiria dvi neretai tapatinamas sq̨vokas - ,, ,rumpinimal" ir santrumpos". Pirmoji sq̨voka taikoma tais atvcjais, kai ilgas biblografinis clementas (paryzdzul, antraste) sutrumpinama vartojant daugtaski. Alkreiptinas demesys i tai, kad antraštes ir atsakomybes duomenu, leidimo ir serijos sticių duomenys paprastai netrumpinami, nebent taip bũ. ty parašyta dokumente. Aisku, kad sio ISBD (G) nurodymo realizavimas gerokai isplecia rengiamo bibliografijos leidinio apimtị. Taciau jis ypac parankus dokumeno kaibos nemokanciam vartotojui, nes padeda lengviau dentifikuoti dokumentą.

ISBD (G) iš dalies reglamentuoja didžiuju raidžiu vartojimą aprašc. Didžiaja raide paprastai rašomas pirmas kiek rašomi ir pirmieji laikmenos žymos, gretutinès antrasés, priedèlines antrastess ir dalinès antraštés žodžiai.

ISBD (G) reglamentuoja spaudos klaidu pateikimą apraše. Jis reikalauja, kad visi netikslumai ar klaidingai parašyti żodżiai bütu rašomi taip, kaip jie pateikti dokumente. Po ju laužtiniuose skliaustuose gali būti parašyt nstic a pa tist taisymą rasoma santrumpa ,i.e." (id est). Taip pat lejIeistas raides, skaitmenis, juos apskliaudžiant laužziniais skliaustais be tarpu.

Didžiają ISBD (G), kaip ir specializuotu ISBD, dali užima elementỵ apibüđinimas. Joje pateikiami ir konlị užtima elementụ apibüdinimas. Joje pateikiami ir kon-
kretūs pavyzdžiai. Jie yra iliustraciniai ir ju taikymas nekretūs pavyz
privalomas.

Beje, leidimo duomenų sąvoka ilgai mūsų literatūroje ir praktikoje apémé ne tik leidima, bet ir dokumento leidimo vietą, leidyklą, metus. ISBD sis terminas reiškia žodi, frazę arba simbolių grupę, nurodančius, kokiam leidimui priklauso dokumentas. O leidimo vieta, leidykla, metai ivardijami kaip skelbimo srities elementai (skelbimo ir/ar platinimo vieta, leidéjo ir/ar platintojo vardas, skelbimo ir/ar platinimo data)

ISBD (G) A priede yra pateiktos daugialygio apra-

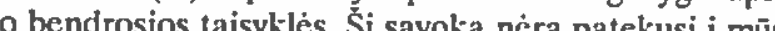

terminu žodynus, tačiau tarptautincje praktikoje yra paplitusi. Ji reiskia vieną iš bibliografinio aprašo bũdụ dorašu sudarymo būdai: a) aprašai, kai pagrieno lygio aptè yra bendra visoms dalims, o dalinés antraštés pantraskiamos turinio pabaigoje; b) aprasai, rašte laikoma daline antrašté, o bendroji antrašté nuro doma serijos srityje; c) aprašai, kai pagrindiné antraštè yra bendrosios ir dalines antraštés derinys; d) kai kurie dokumento sudétiniu daliu analiziniai aprašai. Darialygis bibliografinis aprašas grindžiamas bibliografiniu duomenụ skirstymu i lygius. Pirmame lygyje pateikiami duomenys, bendri tarpusavyje susijusiu dokumenty visumai, arba tik pagrindinio dokumento duomenys. Antrame ar kituose lygiuose nurodomi atskiry dokumento dalių duomenys.

B priede pateikti vadinamujų dviejų krypčiu ịašu pavyzdziai. Tai mišrüs jiră̌ai, kuriuose vartojamas ra ̌xtas iš kairès ị dešinę ir iš dešinès i kaire.

Kiti tarptautinio standartinio bibliografinio aprašo leidiniai paprastai ịvardijami kaip specializuoti ISBD. Jie skirtt tam tikrų rüsių dokumentams: monografiniams leidiniams ISBD (M), serialiniams leidiniams ISBD (S), neknyginei medżiagai ISBD (NBM), kartografinei medżiagai ISBD (CM), iki $1801 \mathrm{~m}$ išleistoms monografijoms ISBD (A), natoms ISBD (PM), elektroniniams ištekliams ISBD (ER). Analiziniam aprašui skirti „ISBD taikymo sudètinių dalių aprašui nurodymai“".

ISBD (G) ir specializuoti ISBD sudaro viena sistea. Jais labai patogu naudotis, nes visi jie parengti tai-

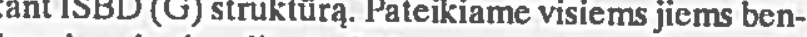

dro pirmojo skyrelio struktūra:

0 [žanginés pastabos

0.1 Apimtis, tikslas ir vartojimas

0.1 .1 Apimtis

0.1 .2 Tikslas

0.1.3 Vartojimas

0.2 Apibrěżimai

0.3 Sandara
0.4 Skyryba

0.5 Duomenu šaltini

0.6 Aprašo kalba ir rašto sistem

0.7 Trumpinimai ir santrumpos

0.8 Didžiuju raidžių vartojimas

0.9 Pavyzdžiai

0.10 Spaudos klaidos

0.11 Simboliai ir t.

Savo numeracija turi aprašo sritys, bibliografiniu bimo jo ati(lomu)) . Tolia sis, 8.1 stand

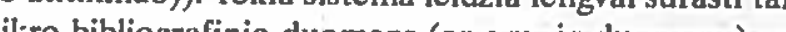
teikimo taisykles ịvairių rưsių dokumentams.

Mondartinis bibDiISBD (G) 
perty pasitarime (Kopenhaga, $1969 \mathrm{~m}$ ) buvo nuspręsta suvienodinti bibliografini apraša katalogams ir bibliogso forma ir turini. ISBD (M) pasirodè $1971 \mathrm{~m}$. kaip rekomena ir ining . dèl buvo nutarta jí pataisyti. $1974 \mathrm{~m}$. pasirodé ISBD (M) pirmasis standartinis leidimas. Véliau teko monografiniụ leidiniu tarptautinị standartini bibliografini aprašą derinti su pasirodžiusiu ISBD (G). $1978 \mathrm{~m}$. išleistas jo pataisytas leidimas, o $1981 \mathrm{~m}$ - ISBD (M) vadovas. Naujas pataisytas leidimas pasirodè 1987 metais. Jame pateikta daugiau terminı ir apibréżimų, labiau atsižvelgta i leidiniu poligrafinio apipavidalinimo specifiką ịvairiose pasaulio šalyse. Bibliografijos ir knygotyros centras 1997 m. paskelbè ISBD (M) vertima i lietuviu kalbą2. ISBD (M) nustato monografiniu leidiniu aprašo ir identifikavimo reikalavimus, apraso elementu tvarką ir ju skyrybą. Monografinio leidinio sąvoka lietuviškame katalogavime nauja. Ji apima lejdinius, susidedancius is vienos dalies arba is anksto żnomo atskiry daliy skaiciaus, islistus reginticsicts ar rellefine forma akliesiems, ir riboto platinimo ar pagal užsakymą platinamus leidinius.

Kaip ir kituose analogiskuose leidiniuose, ISBD (M) pateikiami apibrèzimai tų terminų, kurie vartojami spe-

cialiaja prasme arba viena iš kelių prasmin.
Leidinyje pateikta lyginamoji ISBD (G) ir ISBD (M) sandaros apžvalga. Beje, vertime pateikta sandara naujesnio leidimo negu originale.

ISBD (M) pateikta gerokai dauginu pavyzdzių. Nesuradus tinkamo atvejo, pateikta ir fikttyvių aprašu. Oponentų neturétų piktinti toks rengejjų elgesys, nes jie stengési tik patcikti pavyzdi, kaip elgtis vienu ar kitu sudétingu atveju.

ISBD (M) turi tris priedus. Pirmajame pateikta bendri nurodymai, kaip sudaryti daugialygi apraša. Antrasis priedas gali būti naudingas kataloguotojams ir bibliogtafams, aprašantiems monografinius leidinius Rytu rašmenimis. Paskutiniame priede pateikti aprašu pavyzdžiai. Greičiau rasti reikalingą metodinę rekomendaciją pa
deda "Rodyklè".

Zurnalas "Tarp knygu" isspausdino D. Kastanauskaitès recenzija ${ }^{3}$. Kadangi ji paskelbta profesinėje spau-

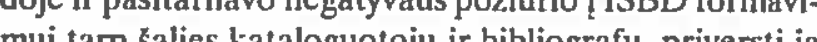

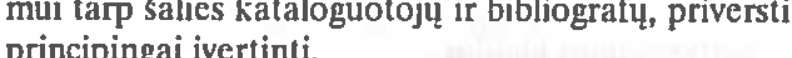
principingai ịvertinti.

Nors ne kartą buvo rašyta, kad ISBD néra tarptautinis standartas, autoré ir toliau mano $j i$ toki esant ir primygtinai siūlo ISBD (M) i lietuviụ kalbą versti „Tarptautinio (!) bibliografinio aprašo standartas (monografinia leidhia) "Anot jos, ,išplèstiné antraštéc kelia nepasitikejima ISBD. Taip keisti aprašo statuta tik tam, a vertim ką vertimą, daugiau negu keista. Kartu ir aptariamu retoj „International Standard Bibliographic Description" rašyti ,International Standard of Bibliographic Descrip-
tion“. Tarptautinius bibliotekininkystès ir bibliografijos standartus priima Tarptautinè standartizacijos organizacija, jie turi ISO santrumpą ir atitinkamą numeri. ISO yra prièmusi tik bibliografiniy nuorody standarus. Recenzijos autoré teigia, kad ISBD (M) nediegiamas ịsakymo tvarka“. Deja, siekiant isvengti anarchijos katalogavimo, bibliografavimo bei déstymo praktikoje, nesant lietuvišku katalogavimo taisykliu, teko imtis ir tokios drastiskos priemonès. Kultūros ministro $1998 \mathrm{~m}$. ruggèjo $28 \mathrm{~d}$, isakymas Nr. 590 n Dèl bibliotekiniu norminiy dokumenty galiojimo" ipareigoja prakța. Autorè teigia, kad „ISBD orientuoja ị antraštini bibliografinị aprašăa“. O koks dar gali būti aprašas, jeigu jo pirmasis elementas visada yra pagrindinè antrašté? Ji net kelia klausima, ,koks bus aprašo (!) pradmuo"? ! Siandien net bibliografijos procesụ kompiuterizavimo specialistai (ne bibliotekininkai!) skiria squvokas „bibliografinio irrašo pradmuo" ir "bibliografinis aprašas".

Beje, autore daugumą savo "novatoriski" pastabu pateikè ne tuo adresu - jas laiku reikéjo pateikti ISBD palaisụ komitetui ir IFLA Katalogavimo sekcijos Nuolatiniam komitetui. Pavyzdžiui, kodèl rengejaai nenurodè, kuo pakeisti lietuviškoje abécélèje trūkstamas raies ir zenklus, kodèl, anot jos, parinko nelabai büdingus lietuviskiems monografiniams leidiniams serijos srities duomenis ir t.t.

Nuostabą kelia autorés iš piršto laužtas tvirtinimas, esą ISBD "mażai gyvastingas". Jau $1974 \mathrm{~m}$. savo valstybines bibliografines apshaitos leidiniuose ISBD (M) naudojo dešimt šaliu, o per pastaruosius 25 metus jų skaičius neregétai išsiplètè. Daugelis Salì pagal jị pataisé savo valstybines katalogavimo taisykles. Priešingai, sunku būtł rasti analogiskas rekomendacijas, kurias perimtụ didžioji pasaulio valstybiụ dalis.

Docentei „kelia abejonę dažnai kartojamas terminas "duomenu perrašymas". Sis kataloguotojo ar bibliografo veiksmas nieko bendra neturi su jo mąstymu ar nemastymu. Ji gerokai paveikta sovietinès katalogavimo praktikos (santrumpu gausybe, ivairił aprašo sričił „pritarsirave tautincje praktikoje duomenț pertasymui visada buvo teikamas tinkamas statusas. Jo prasme buvo ir yra palengunt dokumento identifkavima. Kaip tai svarbu, autore nesunkiaj jsitiknty paka alogavusi leidiniy̨ uzsieio kabomis, kuriy nemoka. Beje, musu iseivijos bib-

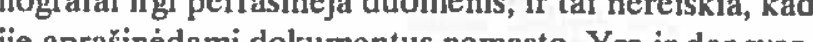
hesnis armuntas Tamtautinis ents aprist r ap trukdytų bibliografinei paicškai kataloge pagal paantraštę ar jos fragmenta skelbimo vieta ir ti.

Kai kurios autorés išvados tiesiog pritrenkia. Pasi- rodo, kad ISBD (M) prasilenkia ne tik su praktika (tai savaime suprantama, nes tokios praktikos iki paskelbian bet ir belir "metoding

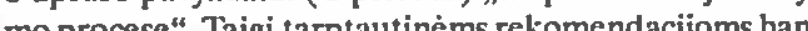
doma suteikti ir mokomojo leidinio statusa?

Galètume ginčytis ir dèl daugelio kittu autorés teiginių (pavyzdžiui, ,kai ịvedame pradmenis, keičiasi antrastes ir atsakomybès duomenu sandara ") bei stebetis kai kuriomis asociacijomis (pavyzdżiui, "mgretutinis" su "gretutiniais kampais"), taciau to padaryti dév vietos stovertima, ji padaré netikètą išvadą apie leidinių bibliogvertima, ji padare netiketą isvadą apie leidiniy̨ bibliog rafinio apipavidalinimo klausimo aktualumą.
gési autorés bandymas jij išspręsti, jau rašème

Naty Ieidiniy tarplaul inis standartinis bibliograf is aprašas ISBD (PM). Parengus ISBD (G) ir ISBD (M), kilo idéja standartizuoti ir natu leidiniy̨ bibliografinio irašo forma ir turini. Tuo tikslu Tarptautiné muzikos biblioteku, archyvy ir dokumentacijos centry asociacija pasiūlè sudaryti su IFLA Katalogavimo komiletu bendrą darbo grupe aprašo projektui parengti. Grupe pradejo dirbti 1976 metais. Jos darbo rezultatai buvo plačiai svarstomi, i gautas pastabas atsižvelgta. $1980 \mathrm{~m}$. pasirodè pirmasis ISBD (PM) leidimas. Vèliau sukaupto pastabos igalino ji pataisyti. Antrasis pataisylas naty ap rašo leidimas paskelbtas 1991 metais. Bibliografijos ir knygotyros centras $1998 \mathrm{~m}$. išleido jo vertima i lietuviu kalbas. Beje, lietuviškojo vertimo pratarmeje nurodyta, kad jis skiriamas bibliografams, hataloguotojams biblio rafinių duomenų bazèms formuoti, leidiniams rengti be literatūros sąrašams sudaryti [p. 7]

Natų leidiniai apima leidinius, isleistus regintiesiem ar reljefine forma akliesiems, ir riboto platinimo ar gal užsakyma platinamus leidinius. ISBD (PM) pirmiausia skirta šiuolaikiniams natų leidiniams. Iki $1801 \mathrm{~m}$. is leistos natos aprašomos pagal ISBD (A) ir ISBD (PM). Leidinyje pateikti apibréžimai tụ terminų, kuric ISBD (PM) vartojami specialiaja prasme arba viena is keliu prasmill. Pavyzdžiui, terminas „tipinis terminas reiškia terminą, apibüdinantị muzikos formą ar žanra Muzikos terminai, rekomenduojami kaip specifiniai medžiagos apibūdinimai, pateikti $\mathrm{C}$ priede.

Kaip iprasta specializuotiems leidiniams, pateikt lyginamoji ISBD (G) ir ISBD (PM) sandaros ap̌̌valga ir isssamus elementıl apibūdinimas su konkrečiais pavyzdžiais.

Aprašo trečiają̧ sritị - natụ leidinių specialiają sritị sudaro duomenys, nurodantys kūrinio natu išsdéstymo for mą, kuri jị skiria nuo kity to paties kürinio formul. Ta naty leidiniú specialieji ir gretutiniai specialieji duomenys. Natu lediniy specialieji duomenys nutodomi terminais, kurie yra natu leidinyje. Prie ju gali bưti prijungiamos aiskinamosios
fiziniu duomenų sričiai
Kaip ir kituose specializuotuose ISBD, šiame yra iprastiniai priedai, skirti daugialygiam aprašui ir dvieju krypčiu irašams.

Analizinis tarplautinis bibliografinis aprašas. $\mathrm{Pa}$ reni bibliogring sudetinių daliu tarptautini standartirencija Briuselyje 1977 metais. Ir tik 1988 m pasirode IFLA Katagavimo ir Serialiniy leidiniy sekcify pasirode tiniu komitety aprobuoti „ISBD taikymo sudétiniu daliy aprašui nurodymai“. $1997 \mathrm{~m}$. Bibliografijos ir knygotyros centras išleido ju vertima i lietuviu kalbą ${ }^{6}$.

Nurodymy pagrindinis tikslas buvo ịtvirtinti tarptautiniu mastu priimtą žurnalu straipsnił̌, monografiju skyriy ir kitokiu ju daliy, atskiry garso irašo takeliy ir kity „kūrinių kûriniuose" aprašo sandarą. Didelis nurodymu privalumas yra tai, kad jie sumažina katalogavim tradicijy ir indeksavimo bei referavimo praktikos skirumus.

Leidinio žžanginése pastabose pabréžiama, kad nurodymu tikslas yra padeti sudaryti analizini aprasą katalogams, bibliografijos leidiniams ir referavimo tamyboms. Visoms istaigoms, išskyrus valstybinés bibliografinès apskaitos centrus, leidžiama laisvai pasirinkti, kuriuos elementus jitraukti. Tačiau su viena salyga - jos privalo laikytis nustatytos elementu pateikimo tvarkos ir ju rašymo reikalavimu, kuriuos nustato ISBD.

Analizinị bibliografinị aprasą sudaro keturios dalys: a) sudétines dalies aprašas, $b$ ) jungiamasis elementas, c) pagrindinio dokumento identikikacija, d) duomenys apie dalies vieta pagrindiniame dokumente. Taigi dokumento sudetine dalis traktuojama kaip dokumentas it jos apraše naudojamos visos ISBD $(G)$ numatytos apra so sritys. Sudètinés dalies aprašo elementai pateikiam taip pat, kaip nustatyta ISBD tiems dokumentams, kuriụ medžiaga ar forma labiausiai atitinka sudétinés dales medžiagą ar forma

Jungiamasis elementas - tai formalus arba sutartinis elementas, siejantis sudétinés dalies aprašą su pagrindinio dokumento identifikacija. Tai gali būti tarpas, du ịstriżi brūkšniai, tarpas ( //) ar fizinę priklausomyb

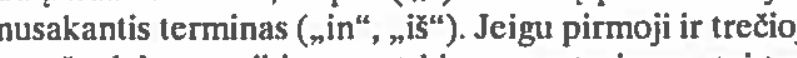
aprašo dalys pateikiamos atskirose pastraipose, tai laras, du ịstriżi brūkšnniai, tarpas praleidžiami.

Pagrindinio dokumento identifikacija taip pat suaroma ISBD (G) pavyzdžiu ir remiasi atitinkamu specializuotụ ISBD nuostatais. Kadangi Y̌ios aprašo dalies tikslas yra tik identifikuoti pagrindini dokumenta, tai rakretụ pagrindinị dokumentą nuo panašaus $i \mathrm{ji}$.

Sudétinès dalies aprašo pabaigoje nurodoma jos
Sagring tiksli vieta pagrindiniame dokumente (puslapiai ir pan.) Pirmoje ir trečioje aprašo dalyse vartojami ISBD mu pri stiti paliek, taška ir vieną arba du tarpus.

Tarptautinio analizinio standartinio bibliografinio 
aprašo naudojimo mūsu కălies praktikoje dažniausiai daroma skyrybos klaidu, nurodant sudétinés dalies vieta pagrindinizme dolumente Jet aprašns knygos, prieš puslapi turi būti rašomas trasssnis ISBD (M)). Sudétinćs đalies, jeinančios i daugiatomi leidini, apraše turi bũti nurodomas tomas ir puslapiai. Santrumpa ${ }_{n} \mathrm{~T}^{\text {." }}$ nurodoma tik tais atvejais, jei క̧s terming yra aprašomame leidinyje. Tomas atskiriamas nuo puslapių kableliu. Aprašant serialiniu leidiniu straipsnius vadovaujamasi ISBD (S) numeracijos srities (3 sritis) ta syklèmis.

Nurodymuose yra du priedai. Pirmasis skirtas daugialygiam aprašui, antrasis pateikia sutrumpintus pavyz džius. Pastarajame pateikti visi nurodytu pagrindiniam tekste pavyzdžių sutrumpinti variantai. Jic labiau tenkna tuos bibliografus ir referentus, kuric siekia bibliografinio aprašo kompak tiškumo.

Karlografinès medxiagos tarptautinis standartin bibliografinis aprasas ISBD (CM). 1973 m. IFLA Gegralijos ir zemelapių bibliotckos sekcija pasiúle paren zemèlapių tarptautinio standartinio bibliografinio apra o projeklą. 1974 m. pabaigoje ikurta darbo grupe per porą metų parenge tris projektus ir iśsamų tekstą. ISBD (CM), kaip Jungtinés darbo grupés rekomendacijos, buvo issleistas 1977 metais. Naujas pataisytas jo leidima pasirodè 1987 metais. Siemet Bibliografijos ir knygotyros centras išleido jo vertimą ị lietuvių kalbą

Kartografinès medžiagos sąvoka apima dvimačius ir trimačius žcmélapius ir planus, skaitmeninius žemèlapius, acronautikos, navigacijos ir dangaus žemélapius, gaublius, blokdiagramas, žemèlapių skyrius, aviacines, palydovines ir kosmines fotografijas, tolimus vaizdus, atasus, vaizdus iš paukščio skrydžio ir panašią medžiage Leidinyje aptartos ir kai kurios specifinès senuju karlografinių leidinių ir žemèlapių rankraščių aprašymo pro-

Apibrèżimu skyrelyje pateikti terminų „žcmélapio

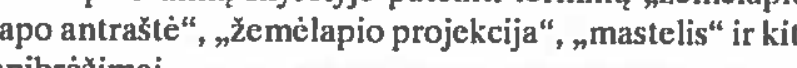
pibréżimai

Kartografinés medžiagos aprašo duomenys pirmiausia imami iš kartografinio dokumento (ji gali sudaryt pats kartografinis dokumentas, deklas ar futliaras, gaub-

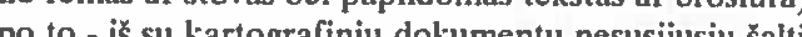
juy (katalogy bibliografijos leidiniy ir pan).

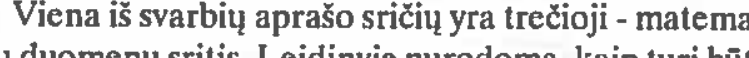
tinity dum sy stilis. Leid os duomenys.

Be iprastu priedu, ISBD (CM) pateiktas specifinity medžiagos apibũdinimų sąrašas, prancūziški ir angližk paryzdžia

Bibliografijos ir knygotyros centro darbuotojai rengia ir kitu rūšiu dokumentu - neknyginés medžiagos, semautinio standa

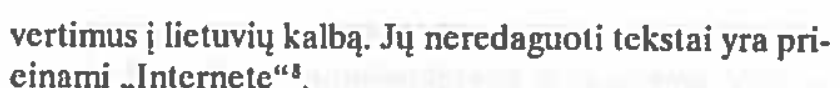

Nrafinis aprašsas ISBD (NBM). Jis apibréżiartinis bibdžiagos aprašo ir identifikavimo reikalavimus, nutsto aprašo elementy pateikimo tvarka ir skyry nés medżagos savoka apima dolumentus, turiy paskintis yra perduoti idéjas, informaciją arba estetini vaizda. Tai garso irožai (garso dist-ai, garso kasetès, garsines knyos sutrikusio regèjimo zmonèms), grafika (atspaudai, atvirukai, bréżinių rinkiniai, nuotraukos, meno reprodukcijos, paveikslai, plakatai ir pan.), kino filmai, mikrodokumentai (mikrofilmai, mikrofišs ir (L) vaizdo iraši (vaizdo diskai, vaizdo kasetés), diafilmai, skaidrés ir panašūs dokumentaj. Šis aprašas netaikomas originaliems meno kūriniams arba radiniams, issskyrus jpakuotus ir parduodamus siekiant pelno, ir kompiuterinius dokumentus. Pastariesiems skirtas elektroninių išstekliu tarptautinis standartinis bibliografinis aprasas ISBD (ER). Sudaryti neknyginès medžiagos aprašą yra sudètingas dalykas, nes joje néra antraštinio puslapio ar atitinkamo atskiro duomeny šaltinio. Bibliografas susiduria ir su jam nežinomais arba menkai žinomais kity sričì tcrminais. Parengti tokị apraš̨̨ buvo nutarta Tarptautiniame katalogavimo ekspertu pasitarime Kopenhagoje 1969 metais. $1975 \mathrm{~m}$. buvo sudaryta ISBD (NBM) darbo grupe, kuri parenge tris projektus ir visą tekstą. Pirmasis jo leidimas, suderintas su ISBD $(G)$, buvo išleistas 1977 metais. Véliau aprasas buvo peržiürétas. Pataisyas ISBD (NBM) pasirodé 1987 metais. Kaip ir kituose specializuotuose leidiniuose, jame randame terminul apibrežimus, kurie ISBD (NBM) vartojami specialiaja prasme arba viena is keleto prasmiul. Medžlagos russitu termnụ apibréžimai pateikti $C$ priede. Be jo yra iprastinia priedai, skirti daugialygiam aprašui ir dvieju krypčiu ịrasams. D priede pridétas rekomenduojamų santrumpu sa rašas, E priede - pavyzdžiai. Reikalingos taisyklés paiešpalengvina rodyklè.

Senuju (antikvariniu) monografiniu leidinių tarptautinis standarlinis bibliografinis aprašas ISBD (A) 8-ojo dešimtmečio pradžiojc buvo prieita pric vienos nuomonès, kad senosios knygos turi savo specifika, kurios nenumato ISBD (M). Pripažinta, kad senuju knygu kaaci bei pertelkti teksto ypatybes, detaliau apibūdinti leidihi. Specialaus apraso senjesiems leidiniams rengimo darbeciali darbo grupe jo projektui parengti. Pirmasis ISBD (A) leidimas pasirode sidare galimybess $\mathrm{Si}_{1}$ aprasą pataisyti. Antrasis pataisyta teidima Vera alkipl dim

ISBD (M) ne iš desmęs i t il, kad ISBD (A) skiriasi ISBD (M) ne is esmes, oth kal kunais sprendimais

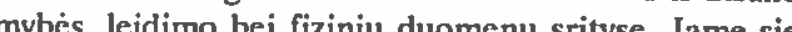

kiama tikslaus antraštès perkẻlimo i apraša, kjek imanoma, islaikant antrastinio puslapio tvarka ir skyryba cau skyrelyje 0.12 nuz emplioriu. Leidinio gale pateikti senuju mo nografiniu leidiniu aprašụ anglu, prancūzų, vokiečiu ir vengrų kalbomis pavyzdžiai

Serialiniu leidiniy Lamtautinis standartinis bibliograninis aprašas ISBD (S). Išankstinis variantas (rekomendacijos) buvo paskelbtas 1974 metais. Paskutini jo varian assurste IFLA Generaliné konferencija 1976 metais Pirsas startini ISBD leidima metais. Pirmasis standartinis ISBD leidimas buvo pa-
skelbtas 1977 metais. Pataisytas ISBD (S) pasirodè 1988 metais. Jame garantuotas suderinamumas su kitais ISBD leidimais ir pataisytu "Guidelines for ISDS". Ş It teidima patvirtino IFLA Katalogavimo ir Serialiniu leidiniu sekcijos.

ISBD (S) pateikia leidiniy (bet kurioje laikmenoje!), leidžiamụ reguliariai arba nereguliariai viena paskui kitą cinančiomis dalimis, kuriụ leidimo trukmé nèra nustatyta (žurnalų, tęstiniu leidinių, laikraš̌čĭ, metinin$\mathrm{k} u$ ir seriju), aprašo taisykles. Jos neaptaria duomeny elementy, kurie apibūdina konkrety serialiniu leidiniy fonda (saugojimo vieta, inventoriaus numeriai ir pan.). Numatoma galimybé bendrajij aprašă papildyti šiais vietinés reikšmès elementais.

Leidinyje paaiskinta, kuo ISDS irašas skiriasi nuo ISBD (S). Pirmojo paskirtis yra tik identifikuoti leidin o ne ji aprasyti, todel svarbiausias jo elementas yra siam tikslui sudaryta speciali registraciné antrašté, vartojam drauge su ISSN.

Archyvinès medžiagos tarptautinis standartinis bỉ liografnnis aprašas ISAD (G). Ji renge Laikinoji aprasomujų standarty komisija Stokhome. Joje $1990 \mathrm{~m}$ buvo jkurtas specialus pognupis. ISAD (G) Madrido projektas buvo patvirtintas 1992 melass. Alsizvelgus i pastabas, jis buvo pataisytas ir $1993 \mathrm{~m}$. sausio men. Tarptautnć archyvụ taryba patvirtino jo galutini variantą. Jo pagrindinis thslas yra garano joll kokybiskų aprasu sudaryma, palengvinti informacijos apie archyvinę medžiaga paiešką ir mainus, sudaryti sąlygas keistis autoritetinias duomenimis ir laiduoti aprašụ iș ivvairių saugykly integravimą i bendra informacijos sistema. Vèliau numatoma parengti archyvinés kartografinės medžiagos, kino filmu, elektroninių ištekliły, sutarčił̧, notariniy raštų, nuo savybės dokumentụ ir pan. aprašo taisykles bei autorite-
tinių irašu standartini aprašą.

Archyvinés medžiagos apraša sudaro tokios sritys: identifikavimo, konteksto, turinio ir sandaros, prieigo ir naudojimo sạlygų, sietines medžagos, pastabu. Iden- tifikuoti aprašomą vienetą, konteksto srityje - informacija apie kilmę ir saugojima, turinio ir sandaros srityje gos ir naudojimo salyou srityje - apie prom formacija apie medžią turinčia svarbiu ny̌̌ su su somuoju vienctu, nurodoma sietines medżigos srityje. Taisyklèse nurodoma, kaip formuluoti informacija kiekviename is 26 elementy. Kiekvienq taisykle sudaq ki rašo elemento pavadinimas, elemento itraukimo ap šą tikslo nurodymas, bendros taisyklés (taisykliu) aprašmas ir payzzdžiai, iliustruojantys taisykles (taisykliut) taikymq

Elektroniniy ištekliy tarptautinis standartinis bibografinis aprašas ISBD (ER) dar tik verčiamas i lietuviu kalba

$1986 \mathrm{~m}$. buvo sudaryta kompiuteriniu rinkmenu (failu) bibliografinio aprašo rengimo grupé. Ji parengé duomeny rinkmeny ir programy aprasa, kuris paskelbtas 990 metais. Vèliau jis buvo pakoreguotas ir vietoj jo $1997 \mathrm{~m}$. pasirodè elektroninių ištekliụ tarptautinis standartinis bibliografinis aprašsas (ISBD) (ER)

Vietoj išvadu. Tarptautinio standartinio bibliografinio aprašo gyvybingumą rodo platus jo paplitimas pasaulyje. Pagal jo reikalavimus buvo pataisytos daugelio saliu valstybinès katalogavimo taisyklés. Śalys, kurios tokiụ taisykliụ neturi, èmè ji naudoti praktikoje tiesiogiai. Pastarajai grupei priklauso ir Lietuva. Besallygiskai perimdama autoritetingu tarptautiniu organizaciju parengtas rekomendacijas, ji sutaupe lešų ir laiko, bũtinu savoms taisyklems rengti, bei sudare sąlygas kokybisku bibliografiniu irašu rengimui. Lietuvos valstybinès bibliog-

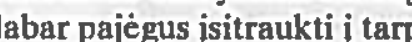
tautinius bibliografinius mainus, isvengdamas papildomy kliū̌ciu, kurias galejo sukelti savy originaliu aprašo taisykliy kũrimas. ISBD siūlomų alternatyvu skaixiy is dalies apribojo ${ }_{n}$ Kompituteriniu bibliografiniu ir autorzuotu irašu sudarymo metodika "9. Be to, ju naudojima nesukels labai diỡeles ivairovés ir nepakenks bibliograInių irašu ir bibliografijos leidinių kokybei

Su ISBD reikalavimais būtina suderinti visas metodikos priemones. Būtinas leidinio „Lietuviškų żodžiu trumpinimas bibliografiniame apraše ${ }^{\star 10}$ pataisytas leidi-

Tarptautiniu lygiu aptarta aprašo terminija. ISBD vertèjai ir redaktoriai rado anglišktu terminų lietuvišskus atitikmenis. Juos būtina įtraukti i rengiama , Bibliotekjninkystés ir bibliografijos terminų żodyna". Neatidélioinas uždavinys yra atnaujinti LST 1350:1994 „Bibliog-

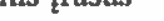
Kai bus isleisti visi ISBD, galima bus svarstyti lietu
visk 
${ }^{1}$ ISBD (G) : bendras tarptautinis standartinis bibliografinis aprašas : anotuotas tekstas / [is anglu kalbos vert
das Macevizius]. - Vilnius, 1995. - [XII], 33 p.

2 ISBD $(\mathrm{M})$ : monografiniy leidiniy tarptautinis standartinis
bibliografinis aprašs / [iš angly kalbos verte Elena Macebibliografinis aprazas / [is angly kalbos verte Elena Mace-
vizỉitte]. - Vilnuius, 1997. 93 p.

3 Kastanauskgité, Danutec. Tarptautinis bibliografinio aprašo tandartas. - Rec. kn.nis bibliografinis aprasas. Vilnius, 1997 // Tarp knygu. - 1998, Nr. 3, p. 16-18.

Varniene, Regina, Janonis, Osvaldas. Katalogavimo dokumentai : tarptautinè praktika ir Lietuva // Tarp knygy. s ISBD (PM) : naty leidiniy tarptautinis standartinis bibliog- rafinis apraşas / [is angly kalbos verté Elena Maceviziātét] 1998. $-87 \mathrm{p}$. kalbos vertè Marija Prokopzike]. - Vilnius, 1997. - 43 p. SBD (CM) : kartografinés medžjagos tarptautinis standa 作 hrokopcike. - Villoius, 1999. - 83 p.

Kompiuteriniu bibliografinity ir autorizuoty jrašu sudarymo metodika. - Vilnius, 1998. - $132 \mathrm{p}$

Lietuvisku žodžiu trumpinimas bibliografiniame aprašco. Vilnius, 1994. - 14 p. - (LST 1350:1994).
Summary

International Standard Bibliographic Description

Osvaldas JANONIS

The development of international co-operation and the creation of international information programmes makes the international unification of bibliography in dispensibli $1 \mathrm{guarant}$ data and at the same lime a possibility of their intermatona exhe amongcount

A short history of International Standard Bibliographic Description (ISBD) is presented in the article, deserion publiations is cho spe tions unaccustomed to bibliographers and cataloguers of the country are presented. The author discusses with ponents of ISBD. A conclusion is drawn that Lithuahia, uncondthonally having taken recommendations prelitup means and time and created conditions for qualitative preparation of bibliographic descriptions quite escription terms is assembled. pared by authoritative international organizations, saapidly. The task to coordinate demands of ISBD with all Lithuanian methodical means, to supplement Lithu-

\section{UDK 070(73)(=882)}

\section{Literatūros mišiniai 1886-1890 m. JAV lietuvių laikraščiuose "Vienybė lietuvninkų" ir "Saulè"}

Jūratè BLAŽEVIČIŪTĖ

Bibliografijos ir knygotyros centras, K. Sirvydo 4, 2600 Vilnius

Redaguojant leidinio „Lietuvos bibliografija. Serija C" $1886-1890 \mathrm{~m}$. grožinès literatūros skyriaus publikaciC' $1886-1890 \mathrm{~m}$ grožinès literatūros skyriaus publikacijas, susiduriama su medzlagos sisteminimo problema. Dadèl nupres sudaryti žn dèl "uspecs suda

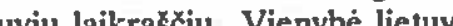
publikacijos is JA "i

Laikraštis Vienybè lietuvninku“ pradétas leisti Pliute 1886 m " Saulec“ - Mahanoi Sityje 1888 metais. mutc 18 aikrašçai yra tiesiogiai susije su D.T. Backausku (1846-1909). Jis buvo pirmasis Vienybés" redaktorius, (18460 $1888 \mathrm{~m}$ leido ir redagavo Saule" Ivairialype ir

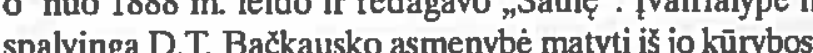
ypat is Ta D. Baco ir kürinèliu kuriy apstu tick viename, tiek kitame laikrasty je. Tačiau D.T. Bačkauskas - ne vienintelis šo żanro kūriniy autorius minètuose leidiniuose. Dirbdamas Vienybèje“, kita savo medžjaga jis pasirašinèdavo "Meisterukas iš "Vienybés", "Saulèje" - "Meisterys nuo "Saulès" arba tiesiog "Meisterukas", o susipažinus su laikražžio tekstais, pasidaro aišku, kad tu "meisteruku“" buvo ne vienas, ir taip buvo vadinami ne vien rašantys laikraščio bendradarbiai, bet ir techniniai redakcijos darbuotojai.

Literatūros mišini būdinti „visko po truputịi. Čia yra satyra, pamfletas, dialogas. Štai „Vienybés" $(1887, \mathrm{Nr}$. 2) publikacijos herojus - Jonas, netikintis i Dievą, Niujorke "rašantis gazietą" tai neabejotinai J. Slliūpas. Kürinèliuose gausiai beriamos savaip perfrazuotos patarlés ir priežodżiai (,jago ant savo vadovy ismisloja, tai tokis sunies neatstoja ", "galva žila, o pasturgalis svyla"), pateikiamos vaizdingos he roju charakteristikos (pplaukai garbiniuoti, akutes kaip żvakutés ir dantelius kožnam rodo "). Yra publicistikos elementu, cituojami laiškai, pacyzdžiui, v. Šmarovskio is Skrantono laiskas su korespondento adresu ${ }_{n} V_{i}$ ienybeje" (1889, Nr. 24). Komentuojami bendruomeneje sklandantys gandai, ivardijami tam tikri asmenys: „Vienybeje "Telegramose del Taradaikos pranesama apie Motieju $A^{* * *}$ iš Niujorko, Heleną $M^{* * *}$ iš Užnemunés, pabégusius skolininkus Onufrą $S^{* * *}$, Juozz̨ $L^{* *}$ ma apie Joną $D^{* * *}$ bali is Klivlendo $(1889, \mathrm{Nr}$. 9). Daž- nai spausdinama užslèpta ar tiesioginé paslaugu, istajgu, laikrašcių reklama.

Eiliuoja trys literatūros misiniy autoriai: DT Bax rodu ir rodele, padainuosim to dainete "(Vienybé. 1887, Nr. 3)), A Turskis (Raudojimas po sermenu Senandoah'e: Ameryke nèr teisybès, negalima butie ..." Ranka in ranka kaipo draugai cikim ." (Vienybe.. 1888, Nr. 35, 52)) ir Q. Ežis ("Dejosi tai liepos nybe. 1888, Nr. 35, 52)) ir Q. Eżis ("Dejosi tai liepos per ruosimas ..." (Vienybé. 1886, Nr. 26, 27)).

Skelbiami ir rubrikos korespondentu eilèraščiai: Dainelé, kurią vienas kunigèlis lietuvninkas ne per seniai paraš́e "(Vienybé 1886, Nr. 13) C.R. eilèraštis , Turu jumis padainuotie" (Saulè. 1889, Nr. 15)

Abjejuose laikraščiuose daugiausia literatūros misiniu publikuota Taradaikos vardu arba be parašo spausdinama Taradaikos rubrik

Aiskinamajame lietuviu kalbos žodyne ${ }^{\top}$ viena iž žodzio "taradaika" reikšmiu - plepus żmogus, tauškalius. Pasirinkdarmas tokị slapyvardi, D.T. Bačkauskas pasirinko ir savo publikaciju stiliu. Rasydamas bet kuria tema (etikos, moraless, spaudos, apie lietuvių bendruomenes JAV aktualijas), autorius Smaikštauja, pajuokia, kritikuoja, giria. Informacija apie ivykius nera issami, nors yra pateikiami faktai, kuriuos interpretuojant atsiskleidżia autoriaus ar laikrasccio pozicija. Taig Tarad aika - reporteris, savo informacija renkantis daugiausia karcemoje, daznal besiremiantis niekuo nepagnistais gandais ir pan. tai sukelia atitinkamą skaitytojų reakcija. Atsiranda Taradaikos gerbeju, rasancił pritarimo laiskus - „Gromata in Taradaika " bei "Antra gromata", pasirasytos "Vieno iš broliü" ir Raulio Kirvio (Vienybé. 1887, Nr. 37) Taciau yra ir pasipiktinimą reiskiancių asmenų - „Komtetas lietuvniku priešaj Taradajka" "(Vienybé. 1889, N 17-18), kurie rašo, kad Taradaika „dabar jau pradéjo joitie ant paties velnio".

Publikuojama ir profesionalesne rašiniy kritika, pavyzdžiui, "Literariška naujiena“, kurioje Zanavykas is .

D.T. Bačkauskas gana aktyviai reiškési visuomentuvos mokslo draugijos steigimo reikalais, buvo Šv. Jur- 